Jurnal Ekonomi dan Industri

Volume 20, No. 1, Januari-April 2019

p-ISSN : 0853-5248

\title{
PENGARUH KUALITAS PRODUK DAN KUALITAS LAYANAN TERHADAP KEPUASAN PELANGGAN DAGING SAPI BEKU DAN SEGAR (Studi Pada Pelanggan PT. Anzindo Gratia International)
}

\author{
Tatag Herbayu Latukismo *) \\ ${ }^{*}$ ) Dosen Program Studi Manajemen FE UNKRIS \\ Alamat: Kampus UNKRIS, Jatiwaringin Jakarta Timur \\ Email: tatagherbayu@gmail.com
}

\begin{abstract}
This study aims to obtain factual and conceptual information about the effect of Product Quality and Service Quality on Customers of PT. Anzindo Gratia International. Questions is structured using a Likert Scale. Samples taken were 40 respondents. The sampling test technique uses the census method and data collection techniques including validity test, reliability test, classic assumption test and multiple linear regression test and hypothesis test. The results of the study, variable product quality and service quality have an influence on simultaneously, the two predictor variables have a fluctuating linear effect on customer satisfaction with a good level of significance. From the hypothesis test known that F count > F table, this shows that the variables Product Quality and Service Quality together have a significant effect on customer satisfaction. Likewise, the variables of product quality and service quality partially contribute significantly to customer satisfaction. From the partial hypothesis testing of each variable namely product quality and service quality it is known that $t$ count $>$ t table, from this shows that the variables Product Quality and Service Quality partially have a significant effect on changes in the value on customer satisfaction at PT. Anzindo Gratia International.
\end{abstract}

Keywords: Product quality, service quality and customer satisfaction

\section{PENDAHULUAN}

Pada era globalisasi, produk atau jasa yang bersaing dalam satu pasar semakin banyak dan beragam akibat keterbukaan pasar. Sehingga terjadilah persaingan antar produsen untuk dapat memenuhi kebutuan konsumen serta memberikan kepuasan kepada pelanggan secara maksimal, karena pada dasarnya tujuan dari suatu bisnis adalah untuk menciptakan rasa puas pada pelanggan. Salah satu tindakan untuk memuaskan konsumen adalah dengan cara memberikan pelayanan kepada konsumen dengan sebaik-baiknya. Kenyataan ini bisa dilihat, bahwa ada beberapa hal yang dapat memberikan kepuasan pelanggan yaitu nilai total pelanggan yang terdiri dari nilai produk, nilai pelayanan, nilai personal, nilai image atau citra, dan biaya total pelanggan yang terdiri dari biaya moneter, biaya waktu, biaya tenaga, dan biaya pikiran (Kotler, 2000).

Oleh karena itu perusahaan harus memulai memikirkan pentingnya pelayanan pelanggan secara lebih matang melalui kualitas pelayanan, karena kini semakin disadari bahwa pelayanan (kepuasan pelanggan) merupakan aspek vital dalam rangka bertahan dalam bisnis dan memenangkan persaingan (Tjiptono, 2004). Bersamaan dengan adanya perubahan lingkungan yang terjadi dan adanya perubahan perilaku manusia, dan aktivitas manusia yang semakin padat setiap harinya, maka semakin mendorong bertambahnya permintaan akan kebutuhan pangan yang lebih bermutu dan bergizi tinggi. Semakin bertambahnya permintaan konsumen akan mendorong para pengusaha di bidang barang 
dan jasa untuk ikut bersaing menawarkan kelebihan-kelebihannya. Banyak faktor yang perlu diperhatikan untuk mempengaruhi kepuasan konsumen salah satunya kualitas layanan yang dapat diberikan oleh perusahaan, kualitas layanan yang baik akan menyebabkan konsumen merasa terpuaskan.

Dengan adanya kualitas layanan yang baik di dalam suatu perusahaan, akan menciptakan kepuasan bagi para konsumennya. Setelah konsumen merasa puas dengan produk atau jasa yang diterimanya, konsumen akan membandingkan layanan yang diberikan. Apabila konsumen merasa benar-benar puas, mereka akan membeli ulang serta memberi rekomendasi kepada orang lain untuk membeli di tempat yang sama.

Menurut Kotler (2001) kualitas layanan merupakan bentuk penilaian konsumen terhadap tingkat layanan yang diterima (percaeived service) dengan tingkat layanan yang diharapkan (Expected service). Tuntutan pelanggan dalam hal layanan yang diterima, menyebabkan pihak pengelola bertindak semaksimal mungkin untuk memberikan layanan yang terbaik bagi konsumen. Kualitas layanan (service quality) dari suatu produk dapat diketahui dengan membandingkan persepsi dari para pelanggan atas layanan yang nyata yaitu produk yang mereka terima dengan layanan yang sesungguhnya sehingga menciptakan kepuasan pelanggan.

Penelitian yang dilakukan oleh V. Mital, WT. Ross dan PM. Baldasare (1998) mengenai tingkat kinerja atribut produk terhadap tingkat kepuasan mengemukakan bahwa kinerja yang negatif pada produk atribut mempunyai efek negatif pada kepuasan keseluruhan dan kinerja yang positif pada produk mempunyai pengaruh positif pada atribut yang sama dan kepuasan keseluruhan menunjukan pengurangan sensitivitas pada tingkat kinerja atribut. Cronin dan Taylor (1992) dalam penelitiannya menemukan hubungan yang positif antara kualitas layanan dan kepuasan pelanggan, dimana kepuasan pelanggan dipengaruhi oleh tingkat kualitas layanan yang mereka terima yaitu keseluruhan kesan yang diterima konsumen terhadap jasa yang mereka tawarkan. Sehingga apabila kedua komponen ini dipenuhi maka akan tercipta kepuasan konsumen terhadap kinerja dari 15 perusahaan.

PT. Anzindo Gratia International merupakan perusahaan dagang yang berlokasi di Jakarta. Dimana produknya adalah daging import beku dan segar yang berasal dari Australia dan New Zealand. Berperan aktif dalam mensuplai daging sapi (frozen beef) dan segar (chilled) guna memenuhi kebutuhan daging dalam negeri yang semakin meningkat, juga untuk menunjang usaha meningkatan gizi masyarakat melalui pemenuhan kebutuhan akan daging sapi sebagai sumber daya hewani.

Persaingan dalam industri pemasok dan suplayer daging beku dan segar dewasa ini semakin ketat, hal ini dapat dilihat dari kompetitor yang semakin banyak bermunculan dan saling banyak menawarkan kelebihan produk-produknya yang akan diberikan kepada pelanggan baik dari segi produk daging beku, segar dan daging olahan lainnya. Untuk mencapai target marketing dalam pasar dan untuk mengantisipasi persaingan pasar maka PT. Anzindo Gratia International mengupayakan untuk mengoptimalkan kualitas produk dan kualitas pelayanannya, karena perusahaan yakin jika kedua hal tersebut dapat dioptimalkan maka konsumen akan terpuaskan dan akan menjadi pelanggan yang loyal.

Dalam upayanya untuk memuaskan konsumen salah satu langkah yang dilakukan oleh PT. Anzindo Gratia International adalah menyediakan produk frozen food berkualitas tinggi yang Aman, Sehat, Utuh dan Halal. Semua produk yang di impor dilengkapi dengan sertifikat Halal dan Kesehatan dari Negara asal, serta melalui proses karantina hewan di Pelabuhan Tanjung Priok dan Bandara. Perusahaan juga memakai gudang dan Cool storage yang terawat dengan baik. Hal ini dilakukan untuk dapat memenuhi kebutuan konsumen serta memberikan kepuasan kepada pelanggan secara maksimal, karena pada 
dasarnya tujuan dari suatu bisnis adalah untuk menciptakan rasa puas pada pelanggan. Salah satu tindakan untuk memuaskan konsumen adalah dengan cara memberikan layanan kepada konsumen dengan sebaik-baiknya

Tujuan penelitian ini adalah untuk mengetahui "Pengaruh kualitas produk dan kuaitas layanan terhadap kepuasan pelanggan daging sapi beku dan segar pada pelanggan PT. Anzindo Gratia International”

\section{LANDASAN TEORI}

\section{Kualitas Produk}

Menurut Handi Irawan MBA.M.Com (2007), konsumen akan memiliki persepsi yang baik, jika konsumen beranggapan bahwa produk tersebut berkualitas baik. Kualitas produk ini adalah dimensi yang global yang terdiri dari: performance (kinerja/fungsional produk), durability (keawetan), Feature (fitur), reability (kehandalan), conformance (kesamaan standar/konsistensi).

Dimensi pertama adalah performance, ini adalah dimensi yang paling dasar dan hubungan dengan fungsi utama dari suatu produk. Konsumen akan kecewa apabila harapan mereka terhadap dimensi ini tidak terpenuhi. Dimensi yang kedua adalah reabiliti, dimensi ini lebih menunjukkan probabilitas produk gagal. Dimensi yang ketiga adalah feature, dimensi ini merujuk pada berbagai fasilitas yang disediakan oleh produk. Dimensi yang keempat adalah durability, dimensi ini menunjukkan suatu pengukuran terhadap siklus produk. Dimensi yang kelima adalah konsistensi, dimensi ini menunjukkan lebih kearah kestrandaran produk.

\section{Kualitas layanan}

Menurut Parasuraman, Zeithaml, dan Berry (dalam Umar, 2003), kualitas layanan merupakan tingkat keunggulan yang di harapkan dan pengendalian atas tinggkat keunggulan tersebut unyuk memenuhi harapan pelanggan, untuk mengevaluasi kualitas jasa pelanggan umumnya mengunakan 5 dimensi sebagai berikut: (1). Tangibles merupakan bukti nyata dari kepedulian dan perhatian yang diberikan oleh penyedia jasa kepada konsumen. Jadi yang dimaksud dengan dimensi tangibles adalah suatu lingkungan fisik dimana jasa disampaikan dan dimana perusahaan dan konsumennya berinteraksi, dan komponen-komponen tangibles akan memfasilitasi komunikasi tersebut. Komponenkomponen tangibles meliputi penampilan fisik seperti gedung, ruangan front office, tempat parkir, kebersihan, kerapian, kenyaman ruangan dan penampilan karyawan. (2). Reliability atau keandalan merupakan kemampuan perusahaan untuk melaksanakaN jasa sesuai dengan apa yang telah dijanjikan secara tepat waktu. Pentingnya dimensi ini adalah kepuasan konsumen akan menurun bila jasa yang diberikan tidak sesuai dengan yang dijanjikan. Jadi komponen dari reliability ini merupakan kemapuan perusahaan dalam manyampaikan jasa secara tepat dan pembebanan biaya secara tepat. (3). Responsiveness atau daya tanggap merupakan kemampuan perusahaan yang dilakukan oleh karyawan langsung untuk memberikan pelayanan yang cepat dan tanggap. Daya tanggap dapat memberikan persepsi yang positif terhadap kualitas jaya yang diberikan. Termasuk didalamnya jika terjadi kegagalan dan keterlambatan dalam menyampaikan jasa, pihak perusahaan berusaha untuk memperbaiki atau meminimalkan kerugian konsumen dengan segera. (4). Assurance atau jaminan merupakan pengetahuan dan perilaku emploiyee untuk membangun kepercayaan dan keyakinan pada diri konsumen dalam mengkonsumsi jasa yang ditawarkan. Jadi komponen dari dimensi ini terdiri dari kompetensi karyawan yang meliputi keterampilan, pengetahuan yang dimiliki karyawan untuk melakukan pelayanan 
dan kredibilitas perusahaan yang meliputi hal-hal yang berhubungan dengan kepercayaan konsumen kepada perusahaan seperti, reputasi perusahaan, prestasi dan yang lainnya. (5). Emphaty merupakan kemampuan perusahaan yang dilakukan langsung oleh karyawan untuk memberikan perhatian kepada konsumen secara individu, termasuk juga kepekaan akan kebutuhan konsumen. Jadi komponen dari dimensi ini merupakan gabungan dari akses yaitu: kemudahan untuk memanfaatkan jasa yang ditawarkan oleh perusahaan, komunikasi merupakan kemampuan untuk menyampaikan informasi kepada konsumen atau memperoleh masukan dari konsumen dan pemahaman merupakan usaha untuk mengetahui dan memahami kebutuhan dan keinginan dari konsumen.

\section{Kepuasan Pelanggan}

Menurut (Tse dan Wilson dalam Tjiptono, 2000) yang menyatakan bahwa kepuasan pelanggan yaitu tingkat dimana anggapan kinerja (perceived performance) produk akan sesuai dengan harapan seorang pelanggan). Ada lima drive utama kepuasan pelanggan yaitu: Drive Pertama adalah kualitas produk. Pelanggan merasa puas setelah membeli dan mengunakan produk tersebut, ternyata kualitasnya baik. Kualitas produk merupakan dimensi global dan ada 6 elemen dari kualitas produk yaitu: performance, durability, reliability, consistency dan design. Driver kedua adalah harga Untuk pelanggan yang sensitif harga murah adalah sumber kepuasan yang penting karena mereka akan mendapatkan value miney yang tinggi. Komponen harga ini relatif tidak penting bagi mereka yang tidak sensitive tarhadap harga. Kualitas produk dan harga sering kali tidak mampu menciptakan keunggulan bersaing dalam hal kepuasan pelanggan. Kedua aspek ini relatif mudah ditiru. Dengan teknologi yang maju dewasa ini, setiap perusahan mampunyai kemampuan untuk menciptakan kualitas produk yang hampir sama dengan pesaing. Dreive ketiga kualitas pelayanan. Kualitas pelayanan sangat bergantung pada tiga hal yaitu: system teknologi dan manusia. Tidak mengherankan kepuasan terhadap kualitas pelayanan biasanya sulit ditiru. Pembentukan attitude dan perilaku yang seiring dengan keinginan perusahaan bukannya hal yang mudah untuk dilakukan oleh perusahaan .pembenahan harus dilakukan mulai dari proses rekruitmen, training budaya kerja dan hasilnya baru dapat dirasakan selama 3 tahun. Konsep kualitas pelayanan diyakini mempanyai lima dimensi antara lain: reliability, responsiveness, assurance, empathy dan tangible. Driver keempat adalah emotional factor. Kepuasan pelanggan dapat timbul dari produk atau jasa yang mereka pakai dan mereka gunakan karena emotional value, yang diberikan dari merk (brand) dari produk tersebut. Rasa bangga, rasa percaya diri, symbol sukses, bagian dari kelompok orang penting dan sebagainya adalah contoh dari emotional value yang mendasari kepuasan pelanggan. Driver kelima hubungan dengan kemudahan untuk mendapatkan produk atau jasa. Pelanggan akan merasa puas apabila relatif mudah, nyaman, dan efisien dalam mendapatkan produk pelayanannya. Selain itu jika pelanggan dengan mudah untuk mendapat produk yang mereka inginkna maka semakin meningkat pula kapuasan dari pelanggan untuk mengunakan produk itu.

\section{METODE PENELITIAN}

Metode penelitian yang digunakan adalah pendekatan explanatory analysis yaitu menjelaskan hubungan kausalistik antar variabEl. Populasi penelitian ini adalah seluruh pelanggan Daging Sapi beku dan segar dari PT. Anzindo Gratia International, jumlah populasi adalah sebanyak 72 pelanggan, yang terdiri dari Industri-industri olahan, hotel, restoran catering dan took daging. Dimana jumlah pelanggan aktif dalam artian yang rutin membeli dalam kurun waktu 1 bulan, adalah sebanyak 40 pelanggan. Dimana teknik 
sampling yang digunakan adalah adalah teknik sampling jenuh. Maksudnya seluruh pembali aktif di gunakan digunakan sebagai sampel.

Teknik yang digunakan untuk mengumpulkan data dalam penelitian dengan cara melakukan kuesioner dan wawancara kepada nara sumber yang berkompeten yaitu pihak PT, Anzindo Gratia International dan pelanggan daging sapi beku dan segar terkait dengan permasalahan dan skala pernyataan yang digunakan adalah skala Likert. Sedangkan data dianalisis secara deskriptif dan kuantitatif. Untuk analisis kuantitatif untuk menjawab permasalahan dan membuktikan hipotesis yang diajukan, yakni melihat pengaruh kualitas produk dan kualitas pelayanan terhadap kepuasan konsumen daging sapi beku dan segar, baik secara simultan maupun secara parsial.

\section{HASIL PENELITIAN DAN PEMBAHASAN}

\section{Uji Validitas}

Uji validitas digunakan untuk mengetahui kelayakan butir-butir pertanyaan dalam suatu daftar (konstruk) pertanyaan dalam mendefinisikan suatu variabel. Daftar pertanyaan ini pada umumnya mendukung suatu kelompok variabel tertentu. Menurut Masrum yang dikutip oleh Sugiyono (2001) menyatakan bahwa syarat minimum untuk dianggap valid adalah $\mathrm{r}=0,30$. Uji validitas dilakukan dengan melihat korelasi antar skor masing-masing item pertanyaan dengan skor total.

Dari hasil perhitungan bahwa dari 27 butir pernyataan dari variabel kualitas produk, kualitas pelayanan, dan kepuasan pelanggan hasilnya adalah valid, dimana nilai dari $\mathrm{R}$ hitung lebih besar dari nilai $\mathrm{R}$ kritis Dengan demikian bahwa seluruh item yang dipertanyakan dalam kuesioner untuk masing-masing variabel layak digunakan sebagai instrumen pengumpulan data. Hasil pengujian validitas dapat dilihat pada tabel 1 dibawah ini.

Tabel 1 Rekapitulasi Hasil Uji Validitas

\begin{tabular}{ccccc}
\hline Keterangan & Kuesioner & R hitung & R kritis & Kesimpulan \\
& Instrumen No.1 & 0.80 & 0.30 & Valid \\
Kualitas Produk & Instrumen No.2 & 0.88 & 0.30 & Valid \\
& Instrumen No.3 & 0.73 & 0.30 & Valid \\
& Instrumen No.4 & 0.40 & 0.30 & Valid \\
& Instrumen No.5 & 0.87 & 0.30 & Valid \\
& Instrumen No.6 & 0.84 & 0.30 & Valid \\
& Instrumen No.7 & 0.89 & 0.30 & Valid \\
& Instrumen No.8 & 0.72 & 0.30 & Valid \\
& Instrumen No.1 & 0.58 & 0.30 & Valid \\
Kualitas layanan & Instrumen No.2 & 0.47 & 0.30 & Valid \\
& Instrumen No.3 & 0.71 & 0.30 & Valid \\
& Instrumen No.4 & 0.50 & 0.30 & Valid \\
& Instrumen No.5 & 0.64 & 0.30 & Valid \\
& Instrumen No.6 & 0.53 & 0.30 & Valid \\
& Instrumen No.7 & 0.79 & 0.30 & Valid \\
& Instrumen No.8 & 0.43 & 0.30 & Valid \\
& Instrumen No.9 & 0.47 & 0.30 & Valid \\
& Instrumen No.1 & 0.90 & 0.30 & Valid \\
Kepuasan Pelanggan & Instrumen No.2 & 0.75 & 0.30 & Valid \\
& Instrumen No.3 & 0.83 & 0.30 & Valid \\
& Instrumen No.4 & 0.50 & 0.30 & Valid \\
& Instrumen No.5 & 0.90 & 0.30 & Valid \\
& Instrumen No.6 & 0.75 & 0.30 & Valid \\
\hline
\end{tabular}




$\begin{array}{cccc}\text { Instrumen No.7 } & 0.83 & 0.30 & \text { Valid } \\ \text { Instrumen No.8 } & 0.50 & 0.30 & \text { Valid } \\ \text { Instrumen No.9 } & 0.54 & 0.30 & \text { Valid } \\ \text { Instrumen No.10 } & 0.50 & 0.30 & \text { Valid }\end{array}$

Sumber : Hasil Olah Data Penelitian

\section{Uji Reliabilitas}

Pada hasil pengujian reliabilitas hasil pengolahan yang telah dilakukan, diperoleh hasil untuk Variabel kualitas produk Nilai Keofisien Alpa sebesar (0.93), pada Variabel kualitas pelayanan Nilai Keofisien Alpa sebesar (0.84) dan Variabel Kepuasan Pelanggan Nilai Keofisien Alpa sebesar (0.91). Diperoleh bahwa semua variabel mempunyai alpha di atas 0.60 yang berarti bahwa semua variabel dalam penelitian ini dapat diandalkan dan dinyatakan reliable. Hasil pengujian Realibilitas dapat dilihat pada table 2 dibawah ini.

Tabel 2. Rekapitulasi Hasil Uji Reliabilitas

\begin{tabular}{cccc}
\hline Keterangan & Koefisien Alpha $(\boldsymbol{\alpha})$ & Standar & Kesimpulan \\
\hline Kualitas Produk & 0.93 & 0.60 & Reliabel \\
Kualitas Pelayanan & 0.84 & 0.60 & Reliabel \\
Kepuasan Pelanggan & 0.91 & 0.60 & Reliabel \\
\hline
\end{tabular}

Sumber : Hasil Olah Data Penelitian

\section{Analisa Hasil Penelitian}

Tabel 3

Pengaruh Kualitas Produk dan Kuaitas Layanan Terhadap Kepuasan Pelanggan

Daging Sapi Beku dan Segar Pada Pelanggan PT. Anzindo Gratia International"

\begin{tabular}{lccccc}
\hline Hubungan & \multicolumn{3}{c}{ Parameter } \\
\cline { 2 - 6 } Variabel & R Square & Konstanta & Keof. & Sig & $\alpha$ \\
\hline Kualitas Produk & & & 2.226 & 0,000 & 0,05 \\
Kualitas Pelayanan & 0,654 & 3.422 & 1.428 & 0,000 & 0,05 \\
Kepuasan Pelanggan & & & & & \\
\hline $\begin{array}{l}\text { Pengujian Signifikansi } \\
\text { F Hitung > F Tabel = 34.905 }>3.244\end{array}$ & & & & \\
\hline
\end{tabular}

Keterangan: Variabel Y Kepuasan Pelanggan

Sumber : Hasil Olah Data Penelitian

Uji F dilakukan untuk melihat apakah keofisien regresi berganda yang ada di model bisa digunakan untuk memprediksikan variabel terikat, hal ini dilakukan apakah variabel bebas secara bersama berpengaruh secara signifikan terhadap terikat. Dari hasil perhitungan diperoleh nilai $\mathrm{F}$ Hitung sebesar 34.905 pada tingkat signifikan 0.05 , dan $\mathrm{F}$ hitung sebesar 3.244. Dengan demikian diketahui F hitung > F tabel, hal ini menunjukkan bahwa variabel bebas secara bersama-sama berpengaruh signifikan terhadap perubahan nilai variabel terikat.

Koefisien determinan $(\mathrm{R}-$ Square $=0,654)$. Kondisi ini juga mampu menjelaskan bahwa kualitas produk dan kualitas pelayanan secara jamak memberikan kontribusi sebesar $65,4 \%$, dan sisanya atau sebesar $34.6 \%$ adalah disumbangkan oleh variabel lain di luar model. 
Persaman regresi linear berganda sebagai berikut $\mathrm{Y}=3.422+2.226 \boldsymbol{X}_{\mathbf{1}}+1.428 \boldsymbol{X}_{\mathbf{2}}$

Berdasarkan persamaan regresi tersebut dapat dijelaskan bahwa kualitas produk dan kualitas layanan berpengaruh positif terhadap kepuasan pelanggan. Hal ini dapat dilihat temuan koefisien penduga, dimana variabel kualitas produk menghasilkan koefisien $(2,226)$ dan variabel kualitas layanan $(1,428)$ dengan masing-masing signifikansi $\alpha=0,05$ melalui penduga ini dapat digambarkan, bahwa kualitas produk memberikan indikasi pengaruh yang relatif lebih tinggi dari pada kualitas layanan. Pengaruh simultan tersebut, diprediksikan untuk penduga konstanta adalah positif sebesar 3,422, artinya secara simultan kedua variabel predictor tersebut memberikan dampak fluktuatif yang linier terhadap kepuasan pelanggan dengan tingkat signifikansi yang baik.

Koefisien regresi kualitas produk adalah sebesar 2.226 yang berarti jika ada perubahan 1 kali pada kualitas produk maka kepuasan pelanggan akan meningkat sebesar 2.226 kali. Hal ini juga berlaku pada koefisien regresi kualitas layanan, yaitu sebesar 1.428, yang berarti jika ada perubahan 1 kali pada kualitas layanan maka kepuasan pelanggan akan meningkat sebesar 1.428 kali. Hal ini dapat dilihat pada tabel 3. di bawah ini.

Dari hasil pengolahan data tersebut telah berhasil dijawab permasalahan hipotesis yaitu ada pengaruh kualitas produk dan kualitas layanan terhadap kepuasan pelanggan. Jadi kedua variabel yang diteliti, yaitu kualitas produk dan kualitas layanan secara bersamasama mempengaruhi kepuasan pelanggan. Dari koefisien regresi yang positif untuk masing-masing variabel independen terhadap kepuasan pelanggan, dapat disimpulkan bahwa semakin baik kualitas produk dan kualitas layanan maka kepuasan pelanggan akan semakin meningkat.

Tabel 4

Pengaruh Kualitas Produk Terhadap Kepuasan Pelanggan Daging Sapi Beku dan Segar Pada Pelanggan PT. Anzindo Gratia International"

\begin{tabular}{lcccccc}
\hline Hubungan & \multicolumn{3}{c}{ Parameter } & & & \\
Variabel & R Square & Konstanta & Keof. & Sig & $\alpha$ & $\mathrm{t}$ \\
\hline Kualitas Produk & 0.481 & 14.997 & 0.436 & 0,000 & 0,05 & 4.943 \\
\hline Pengujian Signifikansi & & & & & & \\
T Hitung $>$ T Tabel $=4.943>0.1618$ & & & & & \\
\hline
\end{tabular}

Keterangan: Variabel Y Kepuasan Pelanggan

Sumber : Hasil Olah Data Penelitian

Jika secara simultan kualitas produk mampu bersinergi dengan kualitas pelayanan sehingga mampu mempangaruhi kepuasan pelanggan, maka suatu hal yang menarik untuk dikaji lebih mendalam adalah bagaimana jika dilihat secara parsial, apakah kualitas produk mampu mempengaruhi kepuasan pelanggan.

Sebagai temuan pada penelitian adalah, bahwa secara langsung dan parsial (sendiri) kualitas produk berpengaruh positif terhadap kepuasan pelanggan. Dimana koefisien penduga, pada variabel kualitas produk menghasilkan koefiesien $(0,436)$ dengan signifikan untuk $\alpha=0,05$. Melalui penduga ini dapat dijelaskan, bahwa kualitas produk memberikan indikasi pengaruh yang positif. Pengaruh parsial tersebut, diprediksikan untuk penduga konstanta adalah positif sebesar 14,997 dengan $\alpha=0,05$. Artinya secara parsial variabel prediktor tersebut memberikan dampat fluktuatif yang linier terhadap kepuasan pelanggan dengan tingkat signifikansi yang sangat baik. Dimana persamaan regresi linier kualitas 
produk terhadap kepuasan pelanggan adalah $\mathrm{Y}=14 ., 997+0,436 \mathrm{X}_{1}$. Hal ini dapat dijelaskan, bahwa secara parsial variabel kualitas produk tersebut mampu memprediksi kepuasan pelanggan yang positif dan signifikan untuk $\alpha=0,05$ namun memberikan konstribusi yang lemah untuk perubahan yang linier terhadap kepuasan pelanggan. Koefisien diterminan $(\mathrm{R}-$ Square $=0,481)$ dengan estimasi residual yang explaned residual atau sebesar 2,639. Kondisi ini juga mampu menjelaskan bahwa kualitas produk secara parsial memberikan kontribusi kepada kepuasan pelanggan.

Untuk membuktikan hipotesis penelitian bahwa ada pengaruh secara parsial antara variabel kualitas produk dengan kepuasan pelanggan dapat dilihat pada nilai t hitung sebesar 4.943, yang berarti nilai dari t hitung > dari nilai t tabel (0.1618) dengan nilai signifikansi 0.05 , yang berarti terdapat pengaruh terhadap pelaksanaan kualitas produk terhadap kepuasan pelanggan.

\section{Tabel 5}

\section{Pengaruh Kualitas Layanan Terhadap Kepuasan Pelanggan Daging Sapi Beku dan Segar Pada Pelanggan PT. Anzindo Gratia International"}

\begin{tabular}{lcccccc}
\hline Hubungan & \multicolumn{3}{c}{ Parameter } \\
\cline { 2 - 7 } Variabel & R Square & Konstanta & Keof. & Sig & $\alpha$ & $\mathrm{t}$ \\
\hline Kualitas Pelayanan & 0.511 & 27.773 & 0.315 & 0,000 & 0,05 & 2.437 \\
\hline Pengujian Signifikansi & & & & & & \\
T Hitung $>$ T Tabel $=2.437>0.1618$ & & & & & \\
\hline
\end{tabular}

Keterangan: Variabel Y Kepuasan Pelanggan

Sumber : Hasil Olah Data Penelitian

Sebagai temuan pada penelitan adalah, bahwa secara langsung dan parsial (sendiri) kualitas pelayanan berpengaruh positif terhadap kepuasan pelanggan. Temuan koefisien penduga, dimana variabel kualitas pelayanan menghasilkan coeffiesien $(0,315)$ dengan signifikansi $\alpha=0,05$. Hal ini dapat dijelaskan, bahwa kualitas pelayanan memberikan indikasi pengaruh positif. Pengaruh parsial tersebut, diprediksikan untuk penduga konstanta adalah positif sebesar 27,773 dengan signifikansi $\alpha=0,05$. Artinya secara parsial variabel prediktor tersebut memberikan dampat fluktuatif yang linier terhadap kepuasan pelanggan dengan tingkat signifikansi yang sangat baik. Dimana persamaan regresi linier kualitas pelayanan terhadap kepuasan Pelanggan adalah $\mathrm{Y}=27,773+0,315 \mathrm{X}_{2}$.

Selanjutnya dapat dijelaskan, bahwa secara parsial variabel kualitas layanan tersebut mampu memprediksi kepuasan pelanggan yang positif dan signifikan untuk $\alpha=0,05$, namun memberikan konstribusi yang lemah untuk perubahan yang linier terhadap kepuasan pelanggan. Koefisien diterminan $(\mathrm{R}-\mathrm{Square}=0,511)$. Kondisi ini juga mampu menjelaskan bahwa kualitas layanan secara parsial memberikan kontribusi sebesar 51,1\% terhadap kepuasan pelanggan.

Untuk membuktikan hipotesis penelitian bahwa ada pengaruh secara parsial antara variabel kualitas layanan dengan kepuasan pelanggan dapat dilihat pada nilai t hitung sebesar 2.437, yang berarti nilai dari t hitung > dari nilai t tabel (0.1618) dengan nilai signifikansi 0.000 , yang berarti terdapat pengaruh terhadap pelaksanaan kualitas layanan terhadap kepuasan pelanggan. 


\section{KESIMPULAN DAN SARAN}

\section{Kesimpulan}

Dari hasil penelitian mengenai pengaruh faktor kualitas produk dan kualitas pelayanan terhadap kepuasan pelanggan daging sapi beku dan segar pada PT. Anzindo Gratia International dapat ditarik kesimpulan bahwa kualitas produk dan kualitas layanan berpengaruh terhadap kepuasan pelangaan, meskipun masih terdapat faktor lainnya yang tidak ada dalam model yang mempengaruhi kepuasan pelanggan.

\section{Saran}

Dengan berdasarkan pada kesimpulan diatas maka dalam rangka lebih meningkatkan lagi kepuasan pelanggan daging sapi beku dan segar pada PT. Anzindo Gratia International peneliti mengemukakan saran-saran sebagai berikut: Perusahaan diharapkan lebih meningkatkan kualitas produknya agar dapat lebih meningkatkan kepuasan dari pelanggan dengan melakukan evaluasi secara rutin terhadap segala sesuatu yang berkaitan dengan produk daging sapi beku dan segar diantaranya yang berkaitan dengan kinerja produk, keawetan, bagian tambahan dari produk, dan penyediaan produk daging beku dan segar yang berkualitas dan bermutu.

Perusahaan diharapkan lebih meningkatkan kualitas pelayanan agar dapat lebih meningkatkan kepuasan dari pelanggan dengan melakukan evaluasi secara rutin terhadap segala sesuatu yang berkaitan dengan pelayanan dalam penjualan daging sapi beku dan segar diantaranya yang berkaitan dengan penyediaan daging yang berkualitas, dapat diandalkan, bermutu, ketersediaan akan daging yang selalu ada, pelayanan complain dari pelanggan.

\section{DAFTAR PUSTAKA}

Arikunto, Suharsimi,2002, Prosedur Penelitian, Edisi Revisi V, Jakarta : Rineka Cipta.

Assauri Sofian ,2007, Managemen Pemasaran , Dasar , Konsep Dan Strategi Jakarta :Penerbit PT Raja Grafindo Persada.

Astijanto, 2009 , "Aplikasi Praktis Riset Pemasaran Edisi Revisi”, Jakarta: Cetakan Kedua Gramedia Pustaka Utama

Asturi Sri Wahyuni, 2012 “Manajement Pemasaran”, Pamulang: Universitas Terbuka.

Duwi Puritno.2013 "Analisis Korelasi, Regresi Dan Multivariate Dengan SPSS". Yogyakarta: Andi

Gava Media. Ghozali , 2002, "Metode Penelitian ", Jakarta : Penerbit Guna Dharma.

Kotler Armstrong, 2003 "Dasar-Dasar Pemasaran”, Edisi Kesembilan, Jillid Satu, Jakarta : Penerbit PT Indeks Kelompok Gramedia.

Kotler Philip , 2005, “Manajemen Pemasaran”, Jilid II, Edisi 11,Alih Bahasa Benyamin Molan, Jakarta : Indeks.

Kotler, Philip Dan Kevin Lane Keller, 2009“Manajemen Pemasaran”, Jakarta: PT. Indeks.

Kotler, Philip Dan Kevin Lane Keller, 2009“ Manajemen Pemasaran Jasa”, Jakarta: Erlangga.

Kotler Kaller, 2009 "Manajemen Pemasaran“ Edisi 13, Jilid Kedua,. Jakarta ; Erlangga.

Parasuraman, A, Valerie A. Zethami, Leonard L, Berry . (1985 ). " A Conceptual Model Of Service Quality And. Implocations For Future Reseach” . Journal Ofmarketing 49, 41-50 
Rangkuti Freddy. 2013 , "Riset Pemasaran ", Jakarta : PT, Gramedia.

Riduwan,2009, Metode Dan Teknik Menyusun Proposal Penelitian”, Bandung: Penerbit Alfabeta.

Rangkuti Freddy. 2013 , "Riset Pemasaran “, Jakarta : PT, Gramedia.

Ratih Huriyati, "Bauran Pemasaran Dan Loyalitas Konsumen”, Bandung : CV alfabeta, 2008.

Sugiono , 2013, "Metode Penelitian Kombinasi”, Cetakan Ke Tiga, Bandung : Penerbit Alfabeta.

Stanton J. William , 2000 , ” Manajemen Pemasaran“, Jakarta : Salemba.

Tjiptono, Fandy, 2000, "Manajemen Jasa" Yogjakarta : Pernerbit Andi.

Tjiptono, Fandy, 2001, "Demensi dan Prinsib Kualitas Pelayanan," Yogjakarta : Penerbit Andi.

Tjiptono, Fandy, 2006, "Manajemen Jasa , Edisi Pertama" Yogjakarta : Penerbit Andi.

Umar, H. (1997), "Metodologi Penelitian-Aplikasi Dalam Pemasaran”,Jakarta : Gramedia Pustaka Utama. 